\title{
22. PALEOGENE SILICOFLAGELLATES AND EBRIDIANS FROM THE GOBAN SPUR, NORTHEASTERN ATLANTIC ${ }^{1}$
}

\author{
Hsin Yi Ling, Department of Geology, Northern Illinois University²
}

\section{INTRODUCTION}

During Leg 80 of the Deep Sea Drilling Project in the northeastern Atlantic, Paleogene sediments were penetrated at all four of the sites (Figs. 1 and 2). Although the area had been drilled during two previous cruises, Legs 12 and 48, silicoflagellates and ebridians had not been examined until Leg 80 . Subsurface sediments from Site $549\left(49^{\circ} 05.28^{\prime} \mathrm{N}, 13^{\circ} 05.88^{\prime} \mathrm{W}\right.$, water depth $\left.2538 \mathrm{~m}\right)$ were selected for this study of these siliceous microfossils because of the thickness of the Paleogene section and its lithological character.

Samples were processed by standard acidization techniques to separate the siliceous microfossils from the calcareous and organic material, followed by sieving through a $74 \mu \mathrm{m}$ screen. Slides were made from the finer fraction using $22 \times 40 \mathrm{~mm}$ cover slips and Canadian balsam as a mounting medium.

All of the examinations, including photomicrography, were made with a Zeiss photomicroscope. The locations of illustrated specimens on the slides were indicated with application of an England Finder, as in previous studies (e.g., Ling, 1977). All the slides examined will be kept permanently in the micropaleontology collection at the Department of Geology, Northern Illinois University.

\section{RESULTS}

The relative abundances (in percent) of silicoflagellates and ebridians in the samples are shown in Table 1. These were made on the basis of the total population count, thus reflecting the abundance of these siliceous microfossils in the samples and facilitating comparison to coeval deposits from other areas.

Among 24 samples from Cores 549-2 through 549-20, only two samples (549-4-5, 93-95 cm, and 549-2-1, 42$44 \mathrm{~cm}$ ) yielded silicoflagellates. Sample 549-4-5 contains only specimens of Dictyocha hexacantha. Because this species was never abundant throughout its range, its mere presence seems to indicate that the sediments belong to the late middle Eocene $D$. hexacantha Zone of Bukry and Foster (1974) and Bukry (1981). Sample 549-2-1 contains well-preserved silicoflagellates specimens, and the microfloral assemblage is similar to that observed in Hole 549A.

Among the nine samples examined from Cores 549A-10 through 549A-18, five samples from Cores 13 through

\footnotetext{
${ }^{1}$ Graciansky, P. C. de, Poag, C. W., et al., Init. Repts. DSDP, 80: Washington (U.S. Govt. Printing Office).

2 Address: Department of Geology, Northern lllinois University, DeKalb, IL 60115.
}

17 contained silicoflagellates and ebridians. The assemblage composition and the complete absence of both Dictyocha grandis and $D$. deflandrea strongly suggest that the examined sediments are of late middle Eocene to earliest Oligocene age, which corresponds to the upper part of the $D$. hexacantha Zone through the Corbisema apiculata Zone of Bukry (1981). It also equates with the "Unzoned" interval and a part of the Mesocena occidentalis Zone of Shaw and Ciesielski (1983) from Leg 71 located in higher latitude parts of the South Atlantic Ocean.

\section{MICROFOSSIL TAXONOMIC LIST}

The microfossils recovered from the examined sediments have been described or discussed during the past several years, and references are readily available. Consequently, the preferred names used during the investigation are listed in alphabetical order, followed by the original epithets of the taxa. Only limited additional comments are presented for those taxa.

\section{Silicoflagellates}

Corbisema apiculata (Lemmermann) Hanna, 1931, p. 198. pl. D, fig. 2 [ = Dictyocha triacantha var. apiculata Lemmermann, 1901, p. 259, pl. 10, figs. 19 and 20] (Plate 1, Fig. 1).

Corbisema bimucronata Deflandre, 1950, pp. 63/82, 64/82, figs. 174-177 (Plate 1, Figs. 2 and 3).

Corbisema inermis inermis (Lemmermann) Bukry, 1976, p. 892, pl. 5, Figs. 1-3 [ = Dictyocha triacantha var. inermis Lemmermann, 1901, p. 259, pl. 10, Fig. 21] (Plate 1, Fig. 4).

Corbisema recta (Schulz) Ling, 1972, pp. 155, 156, p1. 24, figs. 6 and 7 [ = Dictyocha triacantha var. recta Schulz, 1928, p. 250, fig. 32a and b; and Phyllodictyocha recta (Schulz) Deflandre, 1946, pp. 335-337, fig. 1] (Plate 1, Fig. 11).

Corbisema triacantha (Ehrenberg) Hanna, 1931, p. 198, pl. D, fig. 1 [ = Dictyocha triacantha Ehrenberg, 1844, p. 80] (Plate 1, Fig. 5).

Dictyocha aspera aspera Bukry, 1976, p. 723 [ = Dictyocha fibula var. aspera Lemmermann, 1901, p. 260, pl. 10, figs. 27 and 28] (Plate 1, Fig. 6).

Dictyocha aspera martinii Bukry, 1975, p. 854, pl. 2, figs. 5-8 (Plate 1, Fig. 9).

Dictyocha fibula Ehrenberg, 1839, p. 129. Remarks: A broad species concept is applied for this taxon to include basal ring from rhombic to close to square outline and apical axis either along major or minor axis (Plate 1, Figs. 7 and 8). 10).

Dictyocha hexacantha Schulz, 1928, p. 255, fig. 43 (Plate 1, Fig.

Distephanus crux (Ehrenberg) Haeckel, 1887, p. 1563 [ = Dictyocha crux Ehrenberg, 1840, pp. 307 and 308]. Remarks: In these northeastern Atlantic samples, all the specimens belonging to this taxon are within the size range of those illustrated in Plate 1. Two forms, however, can be distinguished on the basis of alignment of an apical ring, which is either perpendicular or diagonal to the major axis. These two forms are combined in the present population count (Plate 1, Figs. 12 and 13). 


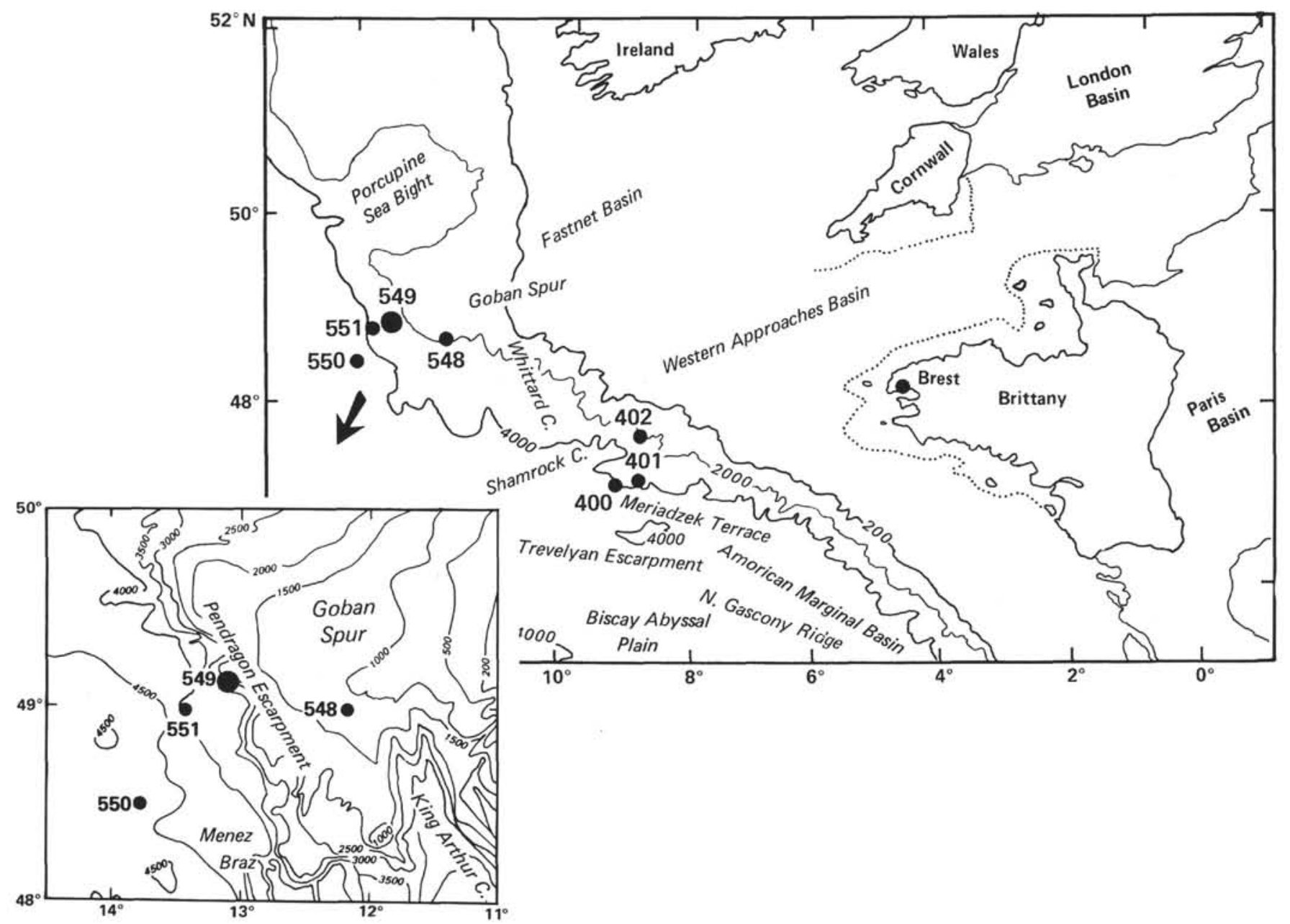

Figure 1. Index map showing the Goban Spur area of the northeastern Atlantic.

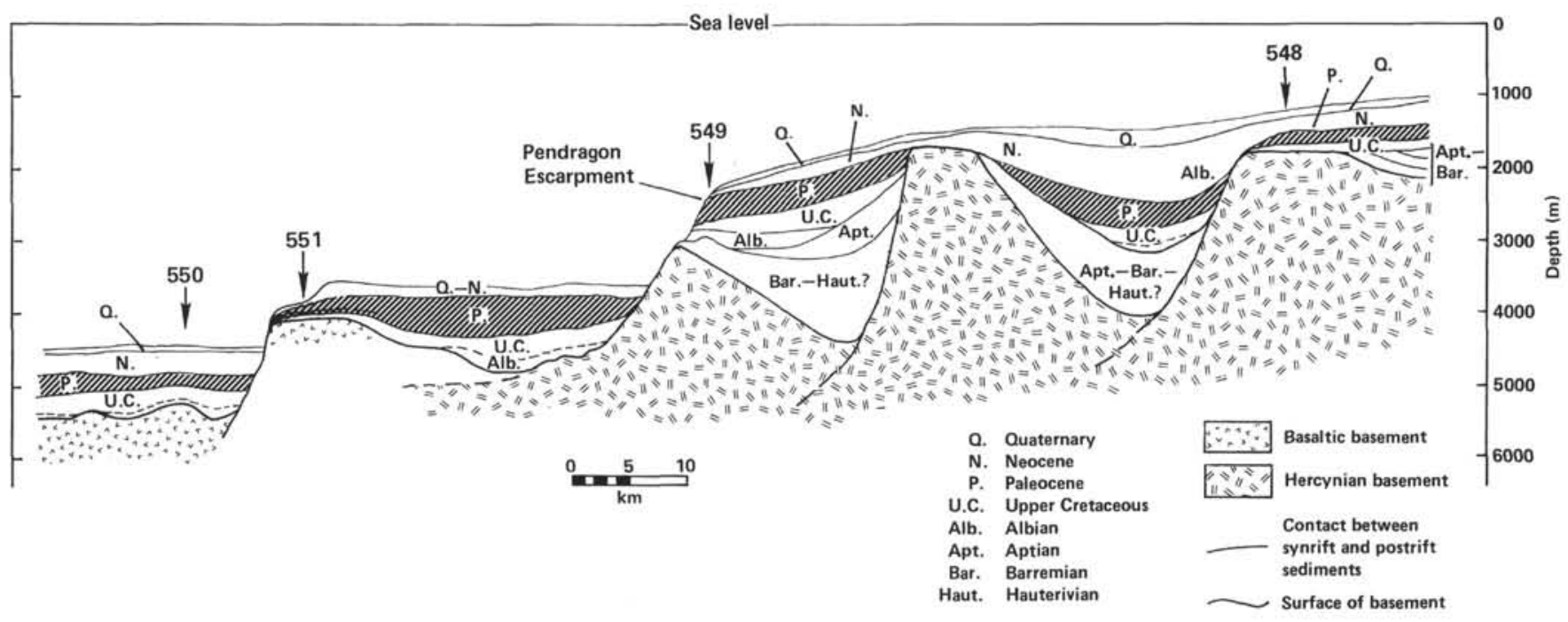

Figure 2. Cross section showing the geologic setting of the Leg 80 drilling sites. 
Table 1. Paleogene silicoflagellates and ebridians (in \%) from Site 549.

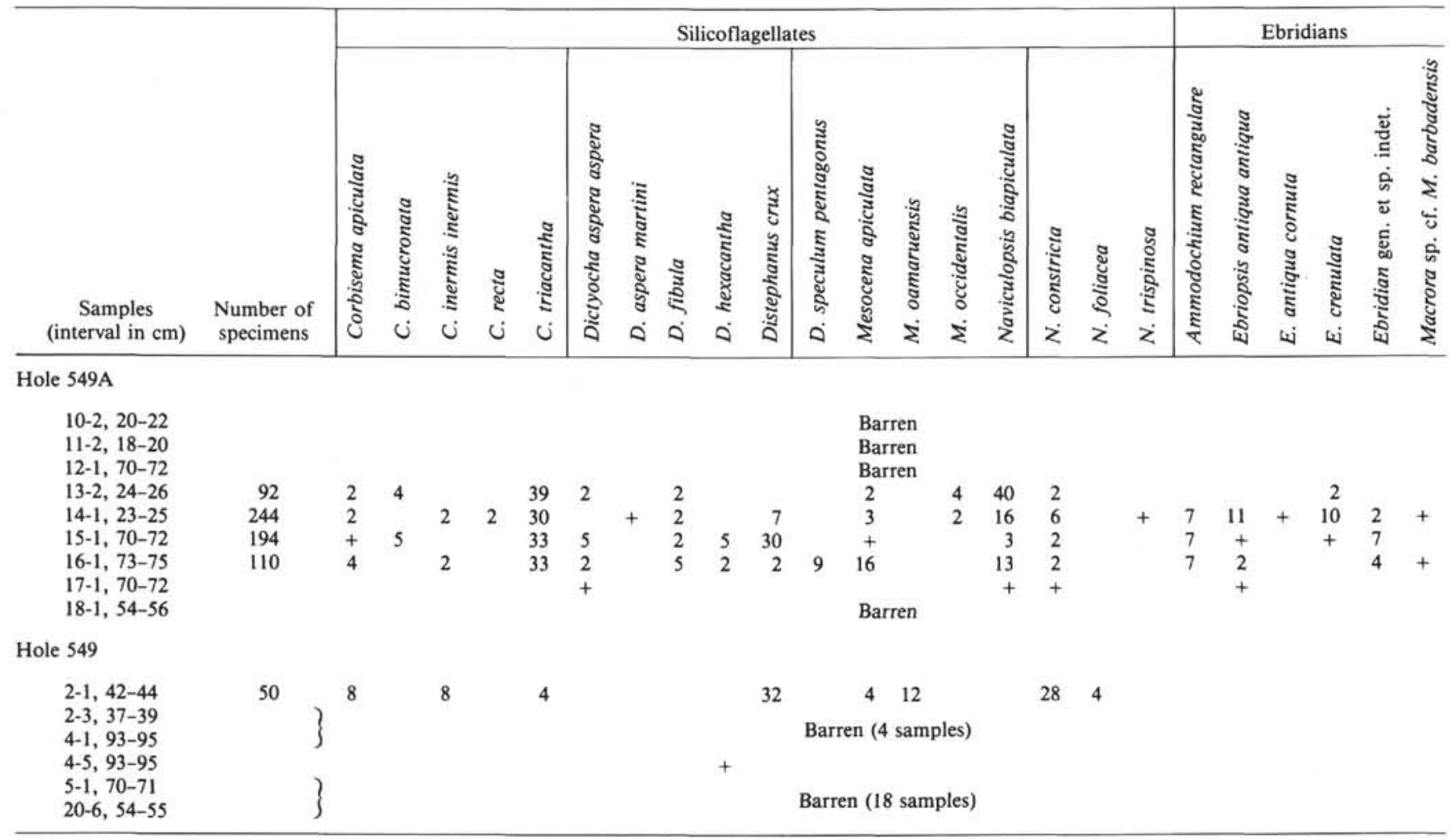

Note: + indicates either a single specimen or an occurrence but the population of the assemblage is too small to measure.

Distephanus speculum pentagonus (Lemmermann) Bukry, 1976, pp. 895-896 [ = Distephanus speculum var. pentagonus Lemmermann, 1901, p. 264, pl. 11, fig. 19] (Plate 1, Fig. 14).

Mesocena apiculata (Schulz) Hanna, 1931, p. 198, pl. D, fig. 3 [ = Mesocena oamaruensis var. apiculata Schulz, 1928, p. 240, fig. 11] (Plate 1, Fig. 15).

Mesocena oamaruensis Schulz, 1928, vol. 21, no. 2, p. 240, fig. $10 \mathrm{a}$ and $\mathrm{b}$ (Plate 1, Fig. 16).

Mesocena occidentalis Hanna, 1931, p. 200, pl. E, fig. 1 [ = Mesocena oamaruensis var. quadrangula Schulz, 1928, p. 240, figs. 12, 13] (Plate 1, Fig. 17).

Naviculopsis biapiculata (Lemmermann) Frenguelli, 1940, p. 60, figs. $11 \mathrm{c}$ and d $[=$ Dictyocha navicula var. biapiculata Lemmermann, 1901 , p. 258 , pl. 10, figs. 14(?) and 15] (Plate 2, Figs. 1-4).

Naviculopsis constricta (Schulz) Frenguelli, 1940, figs. 11a and b [ = Dictyocha navicula var. biapiculata fa. constricta Schulz, 1928, p. 246, fig. 21] (Plate 2, Figs. 5-7).

Naviculopsis foliacea Deflandre, 1950, pp. $76 / 82$ and $77 / 82$, figs. 235-240 [= Dictyocha(?) biapiculata Lemmermann, Hanna, 1931 (part), pl. E. fig. 10 (only)] (Plate 2, Fig. 8).

Naviculopsis trispinosa (Schulz) Glezer, 1966, pp. 258 and 259, pl. 17, fig. 7 [ = Dictyocha navicula var. trispinosa Schulz, 1928, pp. 246 and 247, figs. 23a and b] (Plate 2, Fig. 9).

\section{Ebridians}

Ammodochium rectangulare (Schulz) Deflandre, 1932, pp. 303305, figs. $1-13[=$ Ebria antiqua var. rectangularis Schulz, 1928, p. 274, figs. 72a-d] (Plate 2, Figs. 10-12).

Ebriopsis antiqua antiqua (Schulz) Ling, 1971 (part), p. 693, pl. 1, figs. 21-23 (only) [= Ebria antiqua Schulz, 1928 (part), pp. 273-274, fig. 69b (only)] (Plate 2, Figs. 14 and 15).

Ebriopsis antiqua cornuata Ling, 1977, pp. 215 and 216, pl. 3, figs. $19-22$ [= Ebria antiqua, Schulz, 1928 (part), pp. 273 and 274 , figs. 69e and $\mathrm{f}$ (only)] (Plate 2, Fig. 13).

Ebriopsis crenulata Hovasse, 1932a, p. 281, fig. 4, I and II (Plate 2, Figs. 16-17).
Ebridian gen. et sp. indet. Remarks: Although closely related to Craniopsis Hovasse (1932b), this is apparently a new taxon that requires further detailed examination (Plate 2, Figs. 18 and 19).

\section{Incertae sedis}

Macrora sp. cf. $M$. barbadensis (Deflandre) [ = Pseudorocella barbadensis Deflandre, 1938 (part), p. 91, figs. 1-10 and 12-16 (only)]. Remarks: Bukry (1977) noted that Hanna (1932) previously recorded a similar form as the diatom genus Macrora from the Miocene of California; thus, the latter has a priority over Deflandre's Pseudorocella. The specimens observed in this study show a clearly indented or lobed margin like Miocene Macrora stella, the type species of the genus, yet the pores in both the peripheral and central areas are fewer, like Eocene Pseudorodella barbadensis, which was originally proposed for samples from Barbados and Oamaru, New Zealand (Plate 2, Fig. 20).

\section{ACKNOWLEDGMENTS}

I would like to thank the Leg 80 Scientific Party and the Sample Distribution Panel of the Deep Sea Drilling Project for providing the samples. Special thanks are due to Dr. Paul F. Ciesielski of the University of Florida for sending me a copy of the unpublished Leg 71 article. This paper has also benefitted from the helpful review by Dr. John A. Barron of the U.S. Geological Survey (Menlo Park).

\section{REFERENCES}

Only the references cited in the text and general references for the ebridians are given in the reference list. For the silicoflagellates, readers are directed to the publications starting with Volume 16 of the Initial Reports of the Deep Sea Drilling Project.

Bukry, D., 1977. Coccolith and silicoflagellate stratigraphy, South Atlantic Ocean, Deep Sea Drilling Project Leg 39. In Supko, P. R., Perch-Nielsen, K., et al., Init. Repts. DSDP, 39: Washington (U.S. Govt. Printing Office), 825-839.

1981. Synthesis of silicoflagellate stratigraphy for Maestrichtian to Quaternary marine sediment. In Warme, J. E., Douglas, R. 
G., and Winterer, E. L. (Eds.), The Deep Sea Drilling Project: $A$ Decade of Progress. Soc. Econ. Paleontol. Mineral. Spec. Publ. 32:433-444.

Bukry, D., and Foster, J. H., 1974. Silicoflagellate zonation of Upper Cretaceous to lower Miocene deep-sea sediments. U.S. Geol. Surv. Res., 2:303-310.

Deflandre, G. D., 1932. Remarques sur quelques ébriacées. Bull. Soc. Zool. Fr. 57, No. 4: 302-315.

1938. Sur deux microfossiles siliceux énigmatiques (silicoflagellidées?). Soc. Franc. Microsc. Bull., 7, No. 3: 90-96.

Hanna, G. D., 1932. The diatoms of Sharktooth Hill, Kern County, California. Calif. Acad. Sci, Proc., 4th Ser., 20, No. 6: 161-263.

Hovasse, R., 1932a. Seconde note sur les Ébriacées. Bull. Soc. Zool. Fr., 57, No. 4: 278-283.

Hovasse, R., 1932b. Troisième note sur les Ébriacées. Bull. Soc. Zool. Fr., 57, No. 5: 547-476.

Leg 80 Scientific Party, 1982. Goban Spur transect is drilled. Geotimes, 27, No. 5: 23-25.
Ling, H. Y., 1971. Silicoflagellates and ebridians from the Shinzan diatomaceous member of the Onnagawa Formation (Miocene), Northeast Japan. In Farinnacci, A. (Ed.), II Planktonic Conference Proc., 2:689-703.

, 1977. Late Cenozoic silicoflangellates and ebridians from the eastern North Pacific region. In Saito, T., and Ujiie, H. (Eds.), First Internat. Congr. Pacific Neogene Stratigraphy Proc., pp. 205-233.

Schulz, P., 1928. Beitrage zur Kenntnis fossiler and rezenter Silicoflagellaten. Bot. Archiv, 21, No. 2:225-292.

Shaw, C. A., and Ciesielski, P. F., 1983. Silicoflagellate biostratigraphy of Middle Eocene to Holocene Subantarctic sediments recovered by Deep Sea Drilling Project Leg 71. In Ludwig, W. J., Krasheninnikov, V. A., et al., Init. Repts. DSDP, 71: Washington (U.S. Govt. Printing Office), 687-737.

Date of Initial Receipt: May 10, 1983

Date of Acceptance: August 23, 1983 

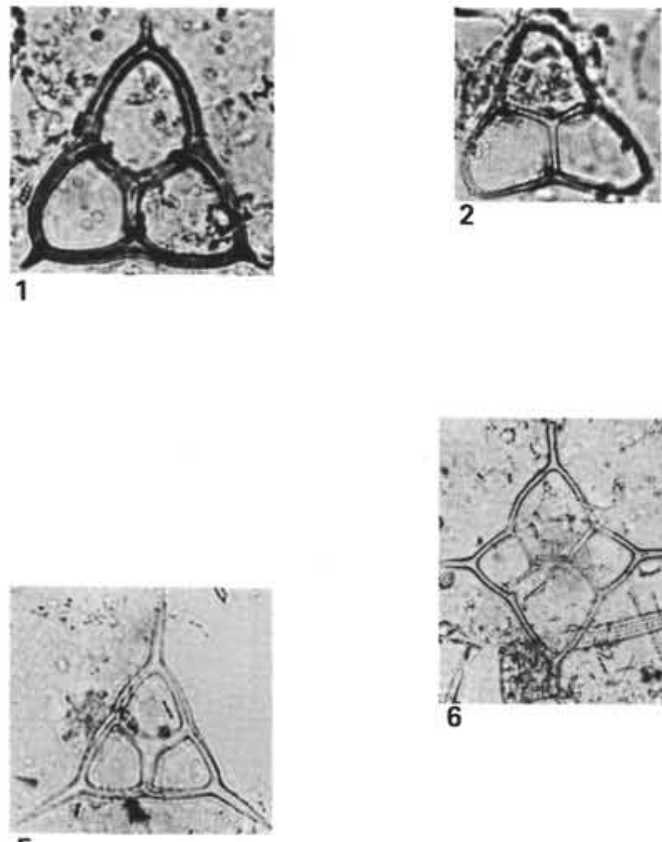

5
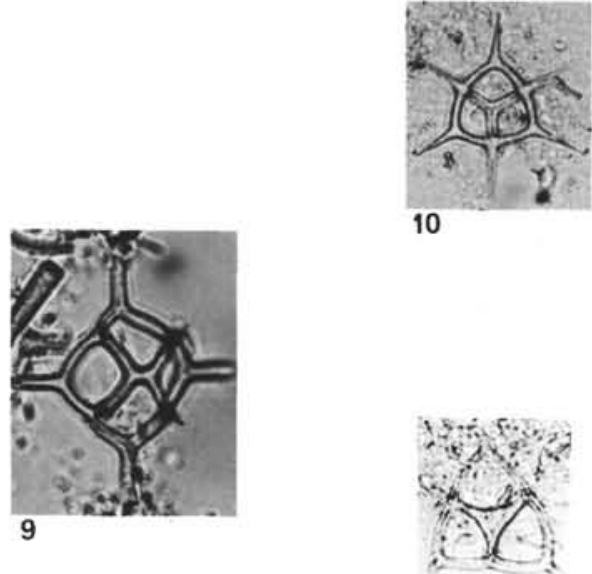

11
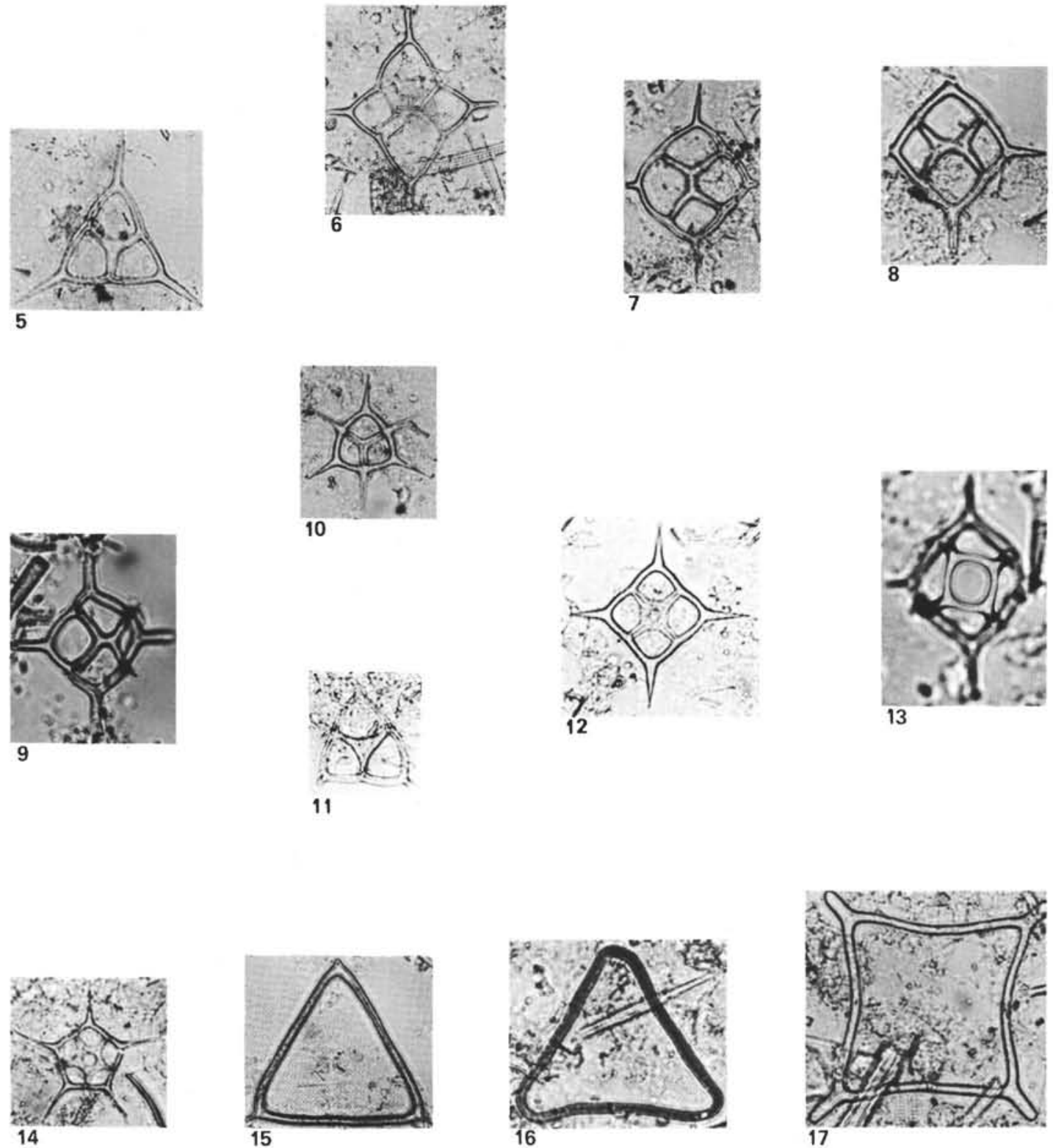

Plate 1. (Magnification $\times 450$ unless otherwise indicated.) 1. Corbisema apiculata, Sample 549-2-1, $42-44 \mathrm{~cm}, \mathrm{~L}-2$ (V17/3). 2-3. C. bimucronata, (2) Sample 549A-14-1, L-2 (K8/4), (3) Sample 549A-13-2, L-2 (X11/1). 4. C. inermis inermis, Sample 549-2-1, L-2 (N32/3). 5. C. triacantha, Sample 549A-16-1, L-2 (G11/3). 6. Dictyocha aspera aspera, Sample 549A-16-1, L-2 (F1/3). 7-8. D. fibula, (7) Sample 549A-132, L-2 (T20/2), (8) Sample 549A-16-1, L-2 (011/3). 9. D. aspera martinii, Sample 549A-14-1, L-2 (F12/0). 10. D. hexacantha, Sample 549-45, L-2 (F27/3). 11. Corbisema recta, Sample 549A-14-1, L-2 (S32/0). 12-13. Distephanus crux, (12) Sample 549A-15-1, L-2 (N36/2), (13) Sample 549-2-1, L-2 (M15/1). 14. D. quinqueangellus, Sample 549A-16-1, L-2 (E4/0). 15. Mesocena apiculata, Sample 549A-16-1, L-2 (X14/ 4). 16. M. oamaruensis, Sample 549-2-1, L-2 (P31/2). 17. M. occidentalis, Sample 549A-14-1, L-2 (P13/1). 

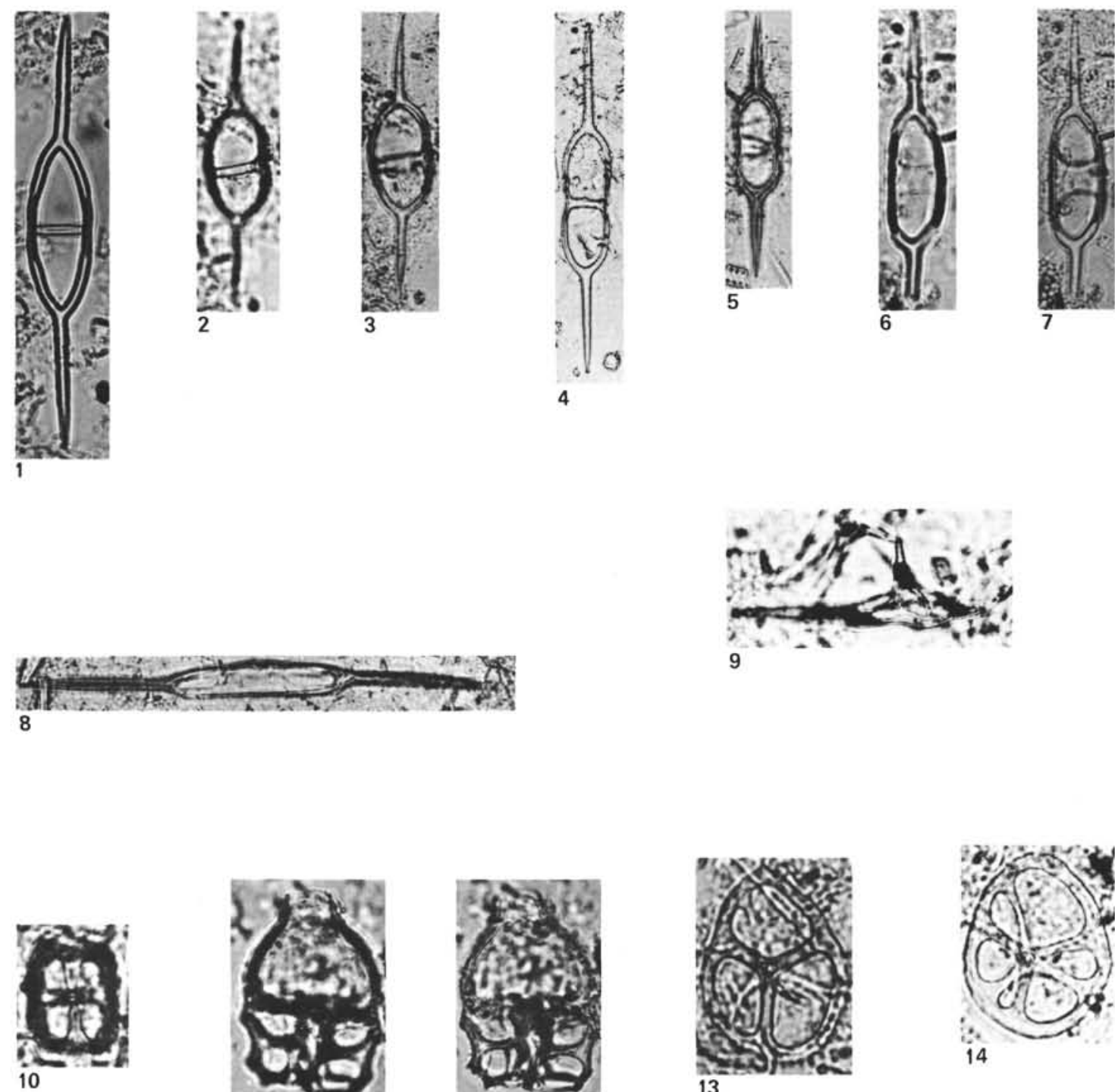

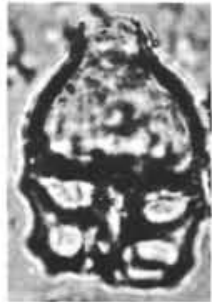

11

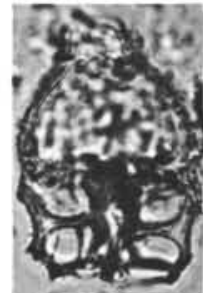

12
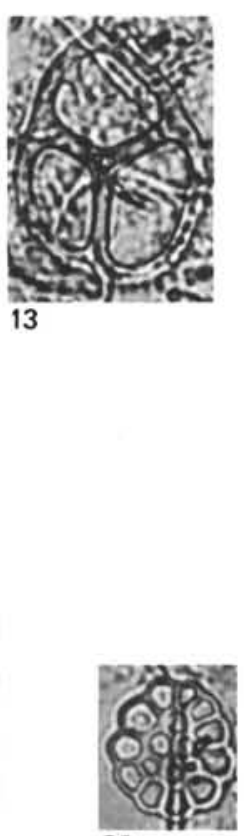

20
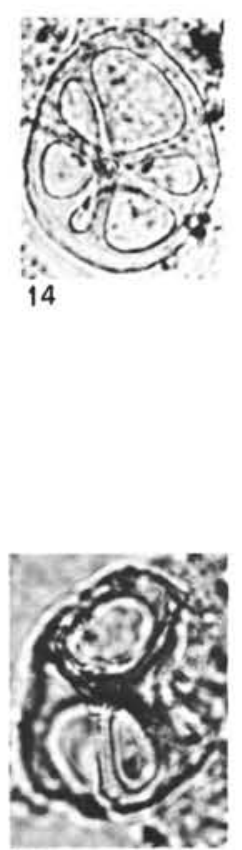

15

Plate 2. (Magnification $\times 450$ for Figs. 1-9, $\times 720$ for Figs. 10-15. 1-4. Naviculopsis biapiculata, (1) Sample 549A-14-1, L-2 (U27/1), (2-3) Sample 549A-16-1, L-2 (G6/0), (4) Sample 549A-14-1, L-2 (G32/1). 5-7. Naviculopsis constricta, (5) Sample 549-2-1, L-2 (Q10/1), (6-7) Sample 549A-13-2, L-2 (016/1). 8. Naviculopsis foliacea, Sample 549-2-1, L-2 (K30/3). 9. Naviculopsis trispinosa, Sample 549A-14-1, L-2 (014/0). 10-12. Ammodochium rectangulare, (10) Sample 549A-15-1, L-2 (V1/1), (11-12) 549A-16-1, L-2 (V34/0). 13. Ebriopsis antiqua cornuata, Sample 549A-14-1, L-2 (J24/0). 14-15. Ebriopsis antiqua antiqua, (14) Sample 549A-15-1, L-2 (F23/0), (15) Sample 549A-17-1, L-2 (H5/0). 16-17. Ebriopsis crenulata, (16) Sample 549A-14-1, L-2 (Y2/2), (17) Sample 549A-14-1, L-2 (U24/0). 18-19. Ebridians gen. et sp. indet., (18) 549A-15-1, L-2 (W28/0), (19) Sample 549A-15-1, L-2 (E12/0). 20. Macrora sp. cf. M. barbadensis, Sample 549A-16-1, L-2 (U21/0). 